\title{
The Influence of Teams-Games-Tournament on Short Stories Learning Outcomes of Grade IV Students: A Study at Elementary School SDN 4 Kabila
}

\author{
Rusmin Husain \\ Department of Elementary Teacher Education \\ Faculty of Education, Universitas Negeri Gorontalo, \\ Indonesia \\ rosmini0460@gmail.com
}

\author{
Juliana Dj \\ Department of Elementary Teacher Education \\ Faculty of Education, Universitas Negeri Gorontalo, \\ Indonesia
}

\begin{abstract}
The objective of this study was to find out the influence of team games tournament (TGT) on short stories learning outcomes of grade IV students; it was conducted in elementary school SDN 4 Kabila, Bone Bolango Regency. This quantitative (experimental) research employed a one-group pretest-posttest design. The primary data were collected from the result of pre and posttest, observation and documentation. The average result of pre and posttest was 54.50 and 82.00 respectively. This result also signifies that Ho is rejected and $\mathrm{Ha}$ is accepted. In conclusion, the application of team games tournament contributes to the learning outcomes of grade IV students in the lesson of short stories.
\end{abstract}

Keywords: teams-games-tournament, learning outcomes

\section{INTRODUCTION}

The quality of education can be enhanced through several approaches. It can be carried out by improving students' learning outcomes upon the completion of learning processes among others. The process of learning is defined as a step in education that provides the students with the opportunity to develop their potentials, involving attitudes, knowledge and skills necessary for daily life [1]. These potentials also help the students to socialize with others for the interest of a community, nationhood and human welfare. Activities of learning must be directed to facilitate the accomplishment of competencies which have been established in a curriculum. This is to nurture the characteristics of independence and life-long learner to the students. Every process undertaken by the students determines the final result of their learning.

Learning outcomes are also defined as the students' educational achievement, which encompasses the affective, cognitive and psychomotor aspects [2]. In addition to teaching, a teacher has a central role and responsibilities as an educator. These responsibilities can increase the success rate of students in learning. Still, students' success is also determined by the quality of teaching and, without question, the internal of the students. A teacher who comprehend their lesson significantly affect the achievement of the students during their study.

Factors that affect the students' abilities and success in learning a particular subject can be seen from their academic achievement. This concept emphasizes that the learning model applied by the teacher is central to ensuring the positive outcomes of the students. The use of the learning model is among the aspects that shape the progress of students' academic conduct. With that being said, a teacher is urged to understand various learning or teaching methods. Applying the most suitable method ensures the effectiveness of most students. Moreover, a teacher needs to be able to create a fun and engaging learning atmosphere to stimulate students' curiosity and to encourage their active participation during the lesson.

The students' learning outcomes in Indonesian language subject is, in fact, poor. Most students do not pay attention to the teacher's explanation because the teaching method is lacking innovation, creativity and variation. This situation blames several factors, such as the ineffective learning model applied during the class. Monotonous learning method causes boredom to students; it also impacts on the students' motivation to learn. The learning model used in teaching the Indonesian subject is mostly conventional, e.g., lectures, questioning and simple group learning. Teachers rarely use other engaging, interesting choices, which is also motivating for the students in the class.

The issue of this study was identified from a preliminary observation and interview with teachers of grade IV in elementary school SDN 4 Kabila, Bone Bolango. The observation reported that oftentimes the teacher prefers the conventional method, such as questioning, lectures and group learning to teach short stories. Those models lead to boredom as it does not cultivate the students' motivation and participation in learning. This situation also affects the learning outcomes of the students. Some of the students in the school are, in fact, unable to meet the minimum mastery criteria for the Indonesian language subject.

The above situation has emphasized the necessity to implement a creative, effective and fun learning model. Among the suitable options is the application of TeamsGames-Tournament model. Reference [3] defines the Teams-Games-Tournament or TGT learning model as one 
of the cooperative learning models in which the students are divided into a group of five to six. The group consists of students with different skills, sexes and races. The uniqueness of TGT model has attracted the teacher's attention as the students will participate in a game or tournament by the end of every learning. Further, the advantage of this model is to foster the students' motivation in learning due to its tournament or competition element. This concept also drives the students' active participation in the class. The group work also encourages the students, regardless of their academic capacities, to cooperate with other members of the group throughout the course.

From the above discussion, this study is to investigate the influence of team games tournament (TGT) on the learning outcomes of grade IV students in learning short stories in elementary school SDN 4 Kabila, Bone Bolango Regency.

\section{LITERATURE REVIEW}

\section{A. Definition of Learning Outcomes}

Reference [4] defines learning outcomes as the changes of a student in terms of their cognitive, affective and psychomotor aspect; the changes are described as a result of learning activities. It is also argues that the learning outcomes also refer to the level of accomplishment of a student in a particular subject [4]. The level is in the form of a score retrieved from evaluation or tests of a set of lessons. Reference [5] further adds that learning outcomes are the abilities possessed by a student after participating in classroom learning; the process of acquiring the new abilities or skills are also accompanied with positive changes of the student, encompassing the affective, cognitive and psychomotor.

Another argument states that learning outcomes are the skills or abilities gained from the student's learning experience [6]. Learning outcomes of the students, i.e., the skills acquired by the students from the process of learning behaviors, can be identified from the students or learners' performance [7]. Further, reference [6] notes that the score or grade functions as the evidence of the new skills that have been learned by the students. The score is from the result of assessing the students' achievement in particular criteria. This tenet implies that the learning outcomes are the assessed object.

\section{B. Factors Affecting Learning Outcomes}

Reference [4] states that the learning outcomes of students are the output of the interaction among all contributing factors, be it internal or external. The detail of the internal factors and external factors are explained in the following paragraph. First, the internal factor refers to those from the inner self of the students which determine the students' learning capabilities. This factor encompasses the students' intelligence, interest, attention, motivation of learning, perseverance, attitude, study habits, and physical and health conditions. Second, the external factor refers to outside influences that impact the students' learning achievement. This factor is from the students' families, school environment and society.

\section{Principles of Learning Outcomes}

Reference [8] has formulated the basic principles of learning outcomes. First, a test must be designed to measure the outcomes of learning outcomes in which the limitation of the measured item has been clearly defined according to the instructional objectives. Second, a test must function as a benchmark of the learning outcomes of a representative sample. It also encompasses the material or lesson of the instructional or teaching program. Third, a test must contain items which are suitable to examine the established learning goal. Fourth, a test must be designed according to the intended use of the test results. Fifth, the reliability of a test must be prioritized; also, the result of the measurement must be interpreted cautiously. Sixth, the test must be able to enhance the learning outcomes of the learners.

\section{Definition of Short Story}

Reference [9] defines the term short story as a piece of prose fiction that tells its readers about a character, predominantly the main protagonist, in a specific setting and a dramatic situation. The term short story is also described as short prose depicting a story of human life with only one problem or conflict and limited characters; the story can be non-fiction or fiction [10]. A short story is an art of telling a story as a whole entity [10]. Although it is considered as only one entity, some short stories may contain more than one element. The number of such prose's elements, however, are not excessive.

Another opinion on the definition of short story is seen in reference [11]; it is argued that short stories are a short literary work in the form of prose. The story has its plot, characters and situations; it should be noted that these components are limited in terms of its number. Furthermore, this type of written literary work tells about certain experiences with more compact plot compared to other forms of prose; it can be read or finished in one sitting [12].

Several intrinsic elements that build a short story involve characters, characterization, plot, setting, theme and message of the story [13].

\section{E. The Concept of Teams-Games-Tournament}

Teams-Games-Tournament or TGT is categorized as a cooperative learning model for its nature in which the students are divided into several groups during the class. De Vries and Slavin developed this model in 1978 at John Hopkins University. The Teams-Games-Tournament or TGT learning model is among the cooperative learning models where the students are divided into a group of five to six. The group consists of learners with different skills and other backgrounds [14]. This opinion resonates to the idea seen in reference [15] that the Teams-GamesTournament or TGT learning model is, by nature, cooperative learning. During the class, the students work in a group of four to five. The grouping does not consider the students' skills, sexes and races.

\section{F. Stages in Teams-Games-Tournament}

The Teams-Games-Tournament or TGT learning model has five stages. These stages, according to Slavin, consists of a class presentation, teams, game, tournament and team recognition [14]. 


\section{G. Advantages and Disadvantages of Teams-Games- Tournament}

Reference [15] mentions several advantages of implementing TGT model. First, students' involvement is improved during classroom learning. Second, the model is able to boost students' motivation. Third, in addition to obtaining the insight from the teacher's explanation, the students can gain knowledge by themselves. Fourth, the TGT model is effective to foster positive self-attitudes, such as teamwork, tolerance and open-minded or accepting opinion from others. Fifth, the provision of reward an appreciation in the TGT model encourages the students to keep aiming higher. Sixth, dividing the students into some small groups help the teacher to monitor the students' activities and cooperation throughout the course. However, the model has its drawbacks. Some of them are mentioned in the research seen in reference [15]. First, the TGT model is timeconsuming, especially for those who are new in teaching. Second, the model requires supporting facilities and infrastructures, such as the questions or instructions of the tournament. Third, the students want to study if there are rewards.

\section{H. The Influence of Teams-Games-Tournament on Learning Outcomes of Elementary Students}

The preliminary observation found that in the research site, the students' learning outcomes in the subject of the Indonesian language is poor. Some of the students did not pay attention to the teachers' explanation. As a result, they have a poor understanding of the lesson. This situation urges the teacher to think creatively in selecting the learning method. Monotonous learning method causes boredom to students; it also lowers the students' motivation in learning. TGT learning model is among the solutions to enhance the students' learning outcomes; it is believed that the model is effective to maximize the students' performance in learning. Further, the advantage of this model is to foster the students' motivation in learning due to its tournament or competition element. This concept ultimately drives the students' active participation in the class.

The tournament activities embedded in the TGT model allow the student groups to compete with each other, meaning that all members of the group, regardless their intelligence or activeness, must partake in the game or the tournament actively. Therefore, the main goal of using the TGT model is to raise the awareness of all students to participate in the learning activities as a group by encouraging the students to win the game. This situation ensures the chance of students other than high achievers to understand the lesson and ultimately boost their achievement.

\section{METHOD}

The rationale for selecting an experimental research method is to find out the influence of the independent variable $(\mathrm{X})$ on the dependent variable $(\mathrm{Y})$. Still, this present study did not involve the control class as a benchmark for the treatment group. Moreover, the sample was not selected randomly. The design of this present study was one group pre and posttest.

This study involved two variables, namely independent and dependent variables. The independent variable refers to a variable that influences others or the one that causes changes in the dependent variable [16]. The TGT model was the independent variable of this study; it is represented by the " $\mathrm{X}$ " letter. Furthermore, the dependent variable of this study, i.e., the variable whose value depends on that of another or the independent one [16]. In this study, the dependent variables were the students' learning outcomes; it is symbolized with the letter "Y".

Population refers to an area of generalization consisting of the object(s) or subject(s) possessing certain qualities or characteristics that meet the needs of the research. The subject(s) or object(s) are further analyzed before coming into a conclusion. The population of this study was the students of grade IV, elementary school SDN 4 Kabila, Bone Bolango Regency. The sample, i.e., a part or characteristics of the research population, involved 14 students of grade IV. These students were selected using a saturated sampling method.

A data collection technique, as reference [16] have claimed, refers to the most strategic stage in research since the main purpose of conducting research is to generate data. Appropriately selecting the data collection method can ensure the objectivity of the data. Some of the methods in collecting data are namely observation, test, treatment and documentation. The instrument of this study was a multiple-choice test consisting of 25 numbers.

Furthermore, the data were analyzed using a validity, reliability and normality test. The Liliefors test was used to examine the data normality.

\section{A. Statistical Hypothesis}

The hypotheses that were examined in this present study are as follows:

$$
\begin{aligned}
& \text { Ho }=\rho=0 \\
& \text { Ha }=\rho \neq 0
\end{aligned}
$$

Description:

Ho $=$ there is no significant influence of Team Game model on students' learning outcomes in studying short stories in grade IV, elementary school SDN 4 Kabila, Bone Bolango Regency.

$\mathrm{Ho}=$ there is a significant influence of Team Game model on students' learning outcomes in studying short stories in grade IV, elementary school SDN 4 Kabila, Bone Bolango Regency.

These hypothesis was examined using a t-test formula as follows:

$$
t=\frac{M d}{\sqrt{\frac{\Sigma X^{2} d}{N(N-1)}}}
$$

\section{Description:}

$\mathrm{Md}=$ mean of the difference between pretest and posttest

$\mathrm{xd}=$ deviation of each subject $(\mathrm{d}-\mathrm{Md})$

$\Sigma \mathrm{X}^{\wedge} 2 \mathrm{~d}=$ number of squares of deviation

$\mathrm{N}=$ subject on the sample

d.b. $=$ determined by $\mathrm{N}-1$ 


\section{RESULTS AND DISCUSSION}

\section{A. Results}

The preliminary observation reported that in the research site, the students' learning outcomes in the subject of the Indonesian language is still below standard. This situation blames in ineffective choose of learning model that the teacher applies. In other words, keep applying the same learning method causes boredom to students by which it impacts on their motivation to learn. Another problem is that the lack of students' engagement in comprehending the teacher's explanation. The above issues have urged a study to investigate the application of Teams-Games-Tournament or TGT model in classroom learning. This study was conducted in elementary school SDN 4 Kabila, Bone Bolango Regency on 26 April 2019.

The objective of this study is to find out the influence of team games tournament (TGT) on the learning outcomes of grade IV students in learning short stories. Further, this study focuses only on one control group participated in the treatment; a pre-test and post-test were administered to the group. The study began by performing the validity and reliability test. Following this step was to assess the students' learning outcomes in discussing short stories before (pretest) and after (posttest) the implementation of TGT learning model.

The collected data were quantitative by nature, focusing on the result of the pre and posttest. The validation of the research instrument, i.e., the multiplechoice test for the students of grade IV in the research site, was also conducted; this step began from 16 April to 22 April 2019. The test consisted of 25 questions; each test or the pretest and posttest have different questions or items. The result of the validation of both pretest and posttest reveals that 15 questions or items are confirmed valid, while the remaining ten questions are invalid. Therefore, only 15 questions were used in both tests for grade IV students or the research subject.

\section{B. Discussion}

According to the research finding, there is a difference between the students' pretest and posttest results. The highest score in the pretest is 87 , while the lowest score is 33 ; this finding is from the test result of all 14 students or the research sample. The overall pretest score of the class reaches 772 with an average measuring at 55.14. After successfully assess the students' pretest, this study proceeds to the next stage, i.e., treatment or the implementation of TGT learning model. This is to examine the influence of the use of the learning model on the achievement of grade IV students in learning short stories.

The result of the treatment finds that the highest score of the posttest is 100, while the lowest score gets 67 . Furthermore, the overall posttest score of the class arrives at 1,181 with an average of 84.36. The next stage was the data analysis using a descriptive statistics model. The analysis finds that the average of the pretest (54.50) has the standard deviation value of 14.79 , while the standard deviation of the posttest (average score 82.00) reaches 8.43. Moreover, the data analysis shows that the normality of the data of variable Y1 (pretest) and variable Y2 (posttest) are normally distributed.
The hypothesis explaining that the TGT model influences the learning outcomes of grade IV students in learning short stories was also performed. The result of this test confirms that the application of TGT contributes to the learning outcomes of grade IV students in discussing the previously mentioned lesson.

The above test is based on the result of t-test at the significance level $(\alpha)=0.05$ gets tcount $>$ ttable. The highest value of tcount is 12.01; this is generated from the data of the distribution of ttable, which arrives at 2.160, meaning that the result is significant. In other words, the result finds that $\mathrm{Ho}$ is rejected and $\mathrm{Ha}$ is accepted. All in all, the hypothesis that the application of TGT contributes to the learning outcomes of grade IV students in discussing the previously mentioned lesson has been proven.

\section{CONCLUSION AND RECOMMENDATIONS}

\section{A. Conclusion}

This present study finds that the application of TeamsGames-Tournament or TGT learning model contributes to the learning outcomes of grade IV students in the lesson of short stories.

\section{B. Recommendations}

From the above results and conclusion, this study has proposed several recommendations for future development. These are explained in the following paragraph.

First, students are expected to increase their active participation in receiving the lesson explained by their teacher during the class, specifically in studying a lesson of short stories. It is essential for them to ace the test on the previously mentioned topic.

Second, the teacher is urged to consider the TGT learning model as the alternative or solution to teaching the Indonesian language subject, especially in the topic of short stories. This suggestion also applies to the school as the TGT model can serve as the reference to improve the quality of education, such as in the language subject. In addition, it is the responsibility of the school to encourage its teachers to apply active, creative and varied learning model to improve the students' learning motivation.

Third, the suggestion for further research is to conduct an in-depth investigation of the implementation of TGT with a wider scope or different perspective for the improvement of the aforementioned learning model in the future.

\section{REFERENCES}

[1] Rusman, Teaching \& Learning (Educational Process-Oriented Standards) [Belajar \& Pembelajaran (Berorientasi Standar Proses Pendidikan)]. Jakarta: Kencana, 2017.

[2] Purwanto, Learning Evaluation [Evaluasi Hasil Belajar]. Yogyakarta: Pustaka Pelajar, 2014.

[3] A, Tri and M. H. Abdullah, "The implementation of teams-gamestournament or TGT cooperative learning in improving elementary school students' learning outcomes in social studies subject [Penerapan model pembelajaran kooperatif tipe teams games tournament (TGT)" untuk meningkatkan hasil belajar IPS siswa sekolah dasar], Jurnal Penelitian Pendidikan Guru Sekolah Dasar, vol 1, 2013, pp. 1-11. 
[4] S. Ahmad, Theories of Teaching and Learning in Elementary School [Teori Belajar \& Pembelajaran di Sekolah Dasar]. Jakarta: Kencana, 2013

[5] Solihah, A., "The influence of teams-games-tournament model on mathematics learning outcomes" [Pengaruh model pembelajaran teams games tournament terhadap hasil belajar matematika]. Susunan Artikel Pendidikan, vol 1, 2016, pp. 45-53.

[6] Husamah, P. Yuni, R. Arina and S. Puji, Teaching and Learning [Belajar \& Pembelajaran]. Malang: Universitas Muhammadiyah Malang, 2018.

[7] S, Jamil. Learning Strategies: Theories and Application [Strategi Pembelajaran, Teori dan Aplikasi]. Jogyakarta: Ar-Ruzz Media, 2013

[8] R. Fauziah and A. Subhananto, "Implementing teams-gamestournament or TGT learning model in improving learning outcomes of grade iii students in discussing a topic of natural resources: A study in elementary school SDN 70 Kuta Raja, Banda Aceh" [Penerapan model pembelajaran TGT (teams games tournament) untuk meningkatkan hasil belajar siswa pada materi sumber daya alam di kelas III SD negeri 70 Kuta Raja Banda Aceh]. Jurnal Tunas Bangsa vol 3, 2016, pp. 43-65.

[9] Sukino, Writing is Easy: A Practical Guide to be a Competent Writer [Menulis itu Mudah (Panduan Praktis Menjadi Penulis Handal)]. Yogyakarta: Pustaka Populer LKSis, 2010.

[10] D. Leonardo, "Improving students' skills in writing a short story through imagination game and mind-map" [Meningkatkan keterampilan menulis cerita pendek dengan bermain imajinasi dan mind map]. Edukasi Kultura: Jurnal Bahasa, Sastra dan Budaya, vol. 1, 2016, pp. 76-85.

[11] Surastina, Introduction to Literature Theories [Pengantar Teor Sastra]. Yogyakarta: Elmatera, 2018.

[12] J. Ketut, D. Nyoman and A. Ni Wayan, "The influence of using mind-mapping on the students' skills in writing a short story: A research on grade V, elementary school in Group II, Buleleng Sub-district, academic year of 2013/2014" [Pengaruh penggunaan media peta konsep terhadap kemampuan menulis cerpen siswa kelas V SD tahun pelajaran 2013/2014 di Gugus II Kecamatan Buleleng]. Mimbar PGSD Undiksha, vol 2, 2014.

[13] Andriani, "Improving skills of analyzing intrinsic elements of short stories using outside circle model: A study on grade XI natural sciences 2 of public senior high school SMAN 1 Polewali, Polewali Mandar Regency" [Peningkatan kemampuan menganalisis unsur intrinsik cerpen dengan model inside outside circle siswa kelas XI IPA2 SMA negeri 1 Polewali Kabupaten Polewali Mandar]. Jurnal Pepatudzu, vol. 11, 2016, pp.19-32.

[14] F. Muhammad, [Innovative Learning Models] Model-model Pembelajaran Inovatif. Jogjakarta: Ar-Ruzz Media, 2015.

[15] D. J. Priansa, Learner's Management and Learning Mode [Manajemen Peserta Didik dan Model Pembelajaran]. Bandung: Alfabeta, 2015

[16] Sugiyono, Quantitative, Qualitative, and R\&D Research Methodology [Metode Penelitian Kuantitatif Kualitatif dan R\&D]. Bandung: Alfabeta, 2010. 